\title{
MUSLIM FOOD CONSUMER PROTECTION THROUGH THE REGULATION OF HALAL LABELS IN INDONESIA
}

\author{
Yuyut Prayuti \\ Universitas Islam Nusantara, Bandung \\ Email: prayutiyuyut@gmail.com
}

\begin{abstract}
The label is a tool to convey information about the products listed on the packaging. In addition to providing information about the product name, the label also provides information on the list of ingredients contained in the product, net weight, durability, value or usefulness of the product as well as information about halal. Objection is the main parameter in the product selection process. This provision makes limitations on food products to enter the Muslim market. This study aims to find out how is the form of legal protection for Muslim food consumers according to the applicable law in Indonesia and Muslim food consumer legal remedies if they feel disadvantaged due to violations of the halal label rules in Indonesia. This research is a Normative Law research through library research. Meanwhile, the normative juridical approach is used. Methods of approach through legislation (Statute Approach) and data sources through the technique of documentation and data analysis through qualitative descriptive. This article concludes that the form of legal protection for Muslim consumers was regulated through the Consumer Protection Act (UUPK) and other laws. Legal efforts by consumers through dispute resolution outside the court and within the court and through the Consumer Dispute Resolution Agency (BPSK).
\end{abstract}

Keyword: Consumer Protection, Halal Food, Muslim, and Regulation.

\section{INTRODUCTION}

Something that is lawful always contains fadhilah (virtue), and everything that is unlawful contains decadence (despicable or bad). For this reason, everything that is unlawful is forbidden and everything that is permissible is recommended. ${ }^{1}$ As explained according to the Qur'an, Surat Al-Mu'minun: 5 which means: "O apostles, eat from good food, and do righteous deeds. Surely I know what you are doing". This is an affirmation and as a reference for Muslims for food products that are consumed every day. From the above verse implies that God wants His servants to be careful in the matter that is eaten in order to choose the halal, and then to fulfill good deeds. This means eating halal something first before fulfilling good deeds. ${ }^{2}$

The food that we consume a lot every day does not all contain nutritional elements or benefits that are good for our body's needs in consuming it especially if it is associated with our beliefs as Muslims. So in Islam, it is recommended to consume halal food or drinks. In order to carry out what is ordered in Islam and maintain faith and devotion to Allah SWT.

\footnotetext{
${ }^{1}$ Bambang Imam Supeno, 2014,Pandangan Imam Al-Ghazali Tentang Halal Dan Haram. Insan Amanah, Surabaya,p. 6

${ }^{2}$ Hasan, K.N. Sofyan Hasan, "Legal Certainty Certification and Labeling of Halal Food Products (Kepastian Hukum Sertifikasi dan Labelisasi Halal Produk Pangan)”. Jurnal Dinamika Hukum, Vol. 14 Number 2, , Pp. 227238. DOI: 10.20884/1.jdh.2014.14.2.292
} 
The development of science and technology nowadays, including the processing of various types of food, is growing rapidly. In the market, there are many various kinds of processed foods thatconsist of domestic and imported products. Many of them are differentkinds of processed food, doubtful halal aspects. The label is a tool to convey information about the products listed on the packaging. In addition to providing information about the product name, the label also provides information on the list of ingredients contained in the product, net weight, durability, value or usefulness of the product as well as information about halal. Halal food is any type of food that does not contain prohibited or unlawful elements or ingredients that are processed according to Islamic laws. Manufacturers who put the word "halal" on the label of their food products are responsible for the halal of these foods for Muslims. ${ }^{3}$

Objection is the main parameter in the product selection process. This provision makes limitations on food products to enter the Muslim market. Ensuring halal food is the responsibility of every Muslim and in this case, the Government is obliged to participate in protecting the interests of Muslims against the halal aspect of the product. To make it easier to find out which foods are halal consumption, especially in packaged foods, it can be seen from the halal label listed on the food packaging. ${ }^{4}$ Labels on food products are very important things to consider.

Indonesia is a country that has the largest number of Muslims in the world, approximately $80 \%$ of the population adheres to Islam. In Islam, halal and haram are part of the Syariah law 'which are opposite each other. Food is said to be halal if based on its nature and how to obtain it. Determining halal is not only in consuming food and drink but also other products. Analyzing halal has its own complexity, starting from the initial manufacturing process, the material used in the manufacturing process to the end of the product, after which it is inaugurated as a halal or haram product. ${ }^{5}$

Halal certificate is an important thing for Muslim consumers because it involves aspects of belief in religious matters and it is the right of every Muslim community to know that the products consumed are in accordance with Islamic law and teachings. The authority to grant halal product labeling is still the domain and authority of Food Processed Product Guarantee Agency the Indonesian Ulama Council (LPPOM MUI). LPPOM as an institution under the Indonesian Ulema Council, is given the authority to provide halal labels so that all food and food products circulating in Indonesia in accordance with the provisions and Islamic law. Halal certification is a form of consumer protection provided by the Indonesian Ulema Council to provide safety and comfort in consuming food for Muslim consumers in Indonesia. ${ }^{6}$ Thus, the purpose of this article is to analyze the forms of legal protection for Muslim food consumers according to the laws in force in Indonesia and Muslim food consumer legal remedies if they feel disadvantaged due to violations of halal label rules in Indonesia.

\footnotetext{
${ }^{3}$ Krishnan, Selvarajah. Mohamad Haniff Hanafi Mohd Aderis. Muhammad Nabil Azman. Mohammad Nazrin Azham Kamaluddin. "Halal Food: Study on Non-Muslim Acceptance". American Journal of Economics, Vol. 7 Number 1. 2017, Pp. 41-45. DOI: 10.5923/j.economics.20170701.05.

${ }^{4}$ Nasution, Bahder Johan.2014, "Efforts to Implement Administrative Sanctions and Licensing as Restrictions on Freedom of Action". Asy-Syir'ah Jurnal Ilmu Syari'ah dan Hukum. Vol. 48 Number 1.. Pp. 211-230. DOI: 10.14421/asysyir'ah.2014.\%25x

${ }^{5}$ Kurniawan. Budi Sutrisno and Dwi Martini, "Responsibilities of Business Actors Regarding Halal Labeling On Food and Beverage Perspective Law Consumer Protection”. Jurnal Penelitian Unram, Vol. 18 Number 1. p. 80-96.

${ }^{6}$ Suparto, Susilowati. "Harmonization and synchronization of institutional arrangements for Halal certification related to the protection of Indonesian Muslim consumers". Jurnal Mimbar Hukum. Vol. 28 Number 3.2016, p. 427-438. DOI: 10.22146/jmh.16674.
} 
In this article, researcher use the statutory approach. This was done because normative legal research as referred to in this study must be related to a certain statutory regulation. As the title protects Muslim food consumers through the regulation of halal labels in Indonesia. then the legislation that will be directly related to this research is the legislation regarding the Consumer Protection Act and Law No. 33 of 2014 concerning Halal Product Guarantees, as well as other relevant laws and regulations.

In normative law research, data which are secondary data are used ${ }^{7}$, seen from how the data is obtained. What is meant by secondary datais data that was available before the holding of this study. Secondary data are usually available for specific purposes rather than specifically provided for this study. Secondary data is usually available in libraries, data and information centers, the internet, and other places that provide secondary data in question. Thus secondary data is often also referred to as library data.

The next stage of collecting research data is to make secondary data referred to as primary legal material, secondary legal material, and tertiary legal material used by researchers in conducting their research. The intended legal material is arranged in a hierarchical manner, where primary legal material has a priority position compared to secondary legal material and tertiary legal material. Whereas secondary legal material has a higher priority compared to tertiary legal material.

In the implementation of primary legal materials, secondary legal materials and tertiary legal materials are collected in accordance with the discussion being carried out and or compiled. The technique used to study and collect these three legal materials is often referred to as documentary study ${ }^{8}$.Because the three legal materials are prepared in relation to one particular discussion, the three types of legal materials must not conflict with each other, but must support each other so that synchronization occurs between the three legal materials. The availability of primary legal materials for a particular subject is more important than the availability of secondary legal and tertiary legal materials. Thus secondary legal materials and tertiary legal materials are positioned as supporting legal materials from primary legal materials. If a particular legal material is not found the primary legal material, then the availability of secondary legal material takes precedence over the availability of tertiary legal material. But if primary legal material and secondary legal material are not available for a particular discussion, then tertiary legal material cannot be used to discuss the intended discussion.

\section{RESULTS AND DISCUSSIONS}

\section{Forms of Legal Protection towards Muslim Food Consumers According to Appli- cable Laws in Indonesia}

Consumer Protection Law is the entire legislation both laws and regional regulations or government regulations and the decisions of judges whose substance regulates the interests of consumers. In consumer protection in Indonesia, there are several parties that play a role in playing its role, including: Consumers, Business actors, the government and other relevant agencies. The role of each in protecting consumers has an important

\footnotetext{
${ }^{7}$ Salim HS., dan Erlies Septiana Nurbani, 2013, Penerapan Teori Hukum Pada Penelitian Tesis Dan Disertasi, RajaGrafindo Persada, Jakarta, , hlm. 12.

${ }^{8}$ Salim HS., Op Cit, hlm. 19
} 
role in the formation of legal protection for all parties involved both consumers and businesses. $^{9}$

The role of consumers and business actors in terms of the legal relations that is formed in terms of consumer protection plays a role so as to create a good relationship between them, thus minimizing the forms of abuse and conflict between the Parties. A product produced by business operators must of course meet certain standards where they will market and sell products to the community.

In Indonesia, almost $80 \%$ of the population are Muslims, so Business Actors and the Government are obliged to maintain the safety of these products both in terms of Islamic Sharia Law and Health. Food that is circulated and consumed by the Muslim community must of course have halal aspects guaranteed by Business Actors, governments and other related institutions so that the Indonesian Muslim community becomes peaceful and calm in consuming a Product on the market which is circulated and made by these Food Business Actors. ${ }^{10}$

Objection is the main parameter in the product selection process. This provision makes limitations on food products to enter the Muslim market. Ensuring halal food is the responsibility of every Muslim and in this case the Government is obliged to participate in protecting the interests of Muslims against the halal aspect of the product. To make it easier to find out which foods are halal consumption, especially in packaged foods, it can be seen from the halal label listed on the food packaging. Labels on food products are very important things to consider.

The Government and related institutions in this matter are the Indonesian Ulema Council is obliged to protect food products for the Muslim community, and is obliged to require through legislation to every Business Actor who has food products to be marketed in Indonesia, it must first be through the mechanism and the halal checking and certification process for its products.

The provisions required in the Islamic Sharia regarding food and its provisions regarding the requirements of halal food meet halal in view of Islamic law, namely: First, does not contain pigs and ingredients derived from pigs. Second, it does not contain khamar and its derivative products. Third, all materials of animal origin must come from halal animals which are slaughtered according to Islamic shari'a procedures. Fourth, it does not contain other substances which are prohibited or classified as unclean, such as: carcasses, blood, materials derived from human organs, feces and so forth. Fifth, all storage, sales, processing, management and transportation facilities for halal products must not be used for pigs or non-halal goods. If it has ever been used for pigs or other non-halal and then it will be used for halal products, then it must first be cleaned in accordance with the method regulated according to Islamic sharia. The use of production facilities for halal and non-halal products in turn is not permitted. ${ }^{11}$

Legal Protection of Muslim Consumers for food products for Muslim communities in Indonesia absolutely must be guaranteed by the State through the Regulation of laws and regulations that are made and applicable to guarantee the protection of Indonesian

\footnotetext{
${ }^{9}$ Hidayat, Asep Syarifuddin and Mustolih Siradj. "Halal Certification and Non-Halal Certification". Jurnal Ahkam, Vol. XV No. 2, 2015, Pp. 99-210. DOI: 10.15408/ajis.v15 i2.2864

${ }^{10}$ Lada, S., Tanakinjal, G.H., and Amin, H. Predicting intention to Choose Halal Products Using Theory Of Reasoned Action. International Journal of Islamic and Middle Eastern Finance and Management. 2(1) (2009) p. 66-76. www.emeraldinsight.com/1753-8394.htm

${ }^{11}$ Aisjah Girindra, 1998, Pengukir Sejarah Sertifikasi Halal , LP POM MUI, Jakarta, hlm. 124-125
} 
Muslim consumers against food products circulating in the market and the Indonesian people. ${ }^{12}$

The forms of legal protection for Muslim consumers in Indonesia include, among others, the Law on Consumer Protection, namely Law No. 8 of 1999 which is often referred to as the Consumer Protection Act (UUPK). In the Law of Consumer Protection Article 8 is a very important aspect for ensuring the Consumer, namely: a) does not meet or does not comply with the required standards and statutory provisions; b) does not correspond to the net weight, net or net contents, and the amount in the calculation as stated on the label or label of the item; c) does not correspond to the size, measurement, scale and amount in the calculation according to the actual size; d) does not comply with the conditions, guarantees, privileges or efficacy as stated in the label, label or description of the said goods or services; e) does not correspond to certain quality, level, composition, processing, style, mode, or usage as stated in the label or description of the said goods or services; f) does not comply with the promises stated in the label, label, description, advertisement or promotion of the sale of said goods or services; g) does not state the date of expiration or the best period of use or utilization of certain goods; h) does not comply with the provisions of halal production, as stated in the "halal" statement stated on the label; i) does not put a label or make a description of the goods that contain the name of the item, size, net or net weight or contents, composition, rules of use, date of manufacture, side effects, name and address of the business actor as well as other information for use which according to the provisions must be installed or made; $j$ ) does not include information or instructions for the use of goods in the Indonesian language in accordance with applicable laws and regulations. ${ }^{13}$

Forms of legal protection for Muslim consumers associated with other legislation is contained in Law no. 18 of 2012 concerning Food, which is contained in Article 95 concerning Guaranteed Halal Products for Required, among others: 1) The Government and Regional Governments supervise the implementation of the halal product guarantee system for those required of Food; 2) The application of the halal product guarantee system for those required as referred to in paragraph (1) is carried out in accordance with the provisions of the legislation.

Protection regarding guarantees for Muslim consumers in obtaining food products that are labeled as halal is regulated in Law No.33 of 2014 concerning the guarantee of halal products contained in Article 4, ie Products that enter, circulate, and trade within the territory of Indonesia must be halal-certified. Furthermore, the regulation regarding the protection of halal products for Muslim consumers in Indonesia is contained in Government Regulation No. 69 of 1999 concerning Food Labels and Advertisement describing halal certification as contained in Article 3, Article 10 and Article 11. Information as referred to in paragraph (1) at least: product name, list of ingredients used, net weight or net content, the name and address of the party producing or importing food into Indonesian territory, the date, month and year of expiration. ${ }^{14}$

\footnotetext{
${ }^{12}$ Nurhayati, Irna. "Effectiveness of Drug and Food Supervisory Agency on Supervision the Distribution of Imported Processed Food Products in Realizing Consumer Protection”. Mimbar Hukum. Vol. 21 Number 2, 2009,. Pp. 203-222. DOI: $10.22146 /$ jmh. 16265

${ }^{13}$ Endah, Nur Hadiati. "Behavior of Giving Cosmetics Labeled Halal by Indonesian Consumers (Perilaku Pemberian Kosmetik Berlabel Halal Oleh Konsumen Indonesia)". Jurnal Ekonomi dan Pembangunan, Vol. 22 Number 1, 2014, Pp. 1125. DOI: 10.14203/JEP.22.1.2014.25-39

${ }^{14}$ Afroniyati, Lies. "The Political Economy Analysis of Halal Certification by the Indonesian Ulema Council (Analisis Ekonomi Politik Sertifikasi Halal Oleh Majelis Ulama Indonesia)". Jurnal Kebijakan \& Administrasi Publik. Vol. 18 Number
} 


\section{Efforts Of Muslim Food Consumers Due To Violations Of Halal Label Rules In Indonesia}

Halal Certificate is a written fatwa issued by MUI stating the halal status of a product in accordance with Islamic sharia. This Halal Certificate is a requirement to include a halal label. ${ }^{15}$ This halal certificate will be issued after going through a research process and declared halal by the Food, Drug and Cosmetics Assessment Institute (LPPOM) MUI. Halal certificates and halal labeling are two different activities but are related to one another. The ultimate goal of halal certification is the existence of formal legal recognition that the product issued has met the halal requirements. Halal labeling is the writing of a halal writing or statement on the product packaging to show that the product in question is a halal product.

LPPOM MUI is a related institution that has the authority and has the right to take legal steps if it is found that the circulation of imported food that is labeled halal but in fact the halal label has never received a halal certificate in its country. Before the legal step was taken, the LPPOM MUI must negotiate or develop so that the company wants to register its product to get a halal certificate whether there is a complaint from a Muslim consumer or not.

LPPOM MUI as an institution which by law is given the authority to oversee the distribution of food that is labeled halal in practice in collaboration with the Agency for Drug and Food Control Agency (BPOM) a government agency that specifically oversees the distribution of food in the community who have the task of Supervision carried out by BPOM is actually only limited to supervision in the case of food testing that is thayyib (good, safe, and higines) of food products that are circulating in the community.

Muslim communities certainly do not all understand related to the forms of violations of the Halal Label on food circulating in the wider community, but if Muslim consumers feel disadvantaged by Business Actors or Food Producers for consumption not in accordance with the rules of the Halal label then as a Consumer can take Legal remedies for objections to a food product food. Related to violations on food product labels committed by business actors, there are sanctions as stipulated in the Consumer Protection Act, the Food Law and PP No. 69 of 1999. These sanctions can be in the form of civil, criminal or administrative sanctions.

Legal remedies that can be carried out by the public who feel disadvantaged due to products that are not in accordance with the provisions of halal law, one of which can take place through the rules stipulated in the Consumer Protection Act, among others: First, take a Dispute Resolution outside the court by adopting Solutions through Negotiation, Consultation, Reconciliation, Mediation and Expert Assessment. As stated in Article 45 paragraph (2) which reads: "Settlement of consumer disputes can be taken through the court or outside the court based on the voluntary choice of the parties to the dispute". Dispute resolution outside the Court does not rule out the possibility of dispute resolution through Peace by establishing a win-win Solution regarding the form of an agreement regarding the amount of compensation. Second, dispute resolution can be taken through the General Court Path by filing a lawsuit related to Unlawful Acts

\footnotetext{
1. 2014,. p. 37-52

${ }^{15}$ Lembaga Pengkajian Pangan, Obat-Obatan dan Kosmetika, PedomanUntuk Memperoleh Sertifikat Halal', MUI Provinsi Jawa Tengah, hlm. 2
} 
and the legal sanctions are usually related to Civil Compensation, but in principle both dispute resolution outside or within the Court does not remove the Alleged Criminal Acts committed by Actors Business regarding certain cases.

In addition to the two Settlements mentioned above, Muslim consumers can also settle disputes over a food product that is not in accordance with the provisions as regulated in Indonesian law, and can also file a lawsuit against producers or business actors to the Consumer Dispute Resolution Board (BPSK) which located in areas including districts or cities in Indonesia.

Further legal remedies as regulated by Law No. 18 of 2012 concerning food is contained in Article 102, namely: Everyone who violates the provisions referred to in Article 97 paragraph (1), Article 99, and Article 100 paragraph (2) is subjected to administrative sanctions. Administrative sanctions referred to in paragraph (1) in the form of: fines, suspension of activities, production or distribution, withdrawal of food from circulation by producers, compensation; or revocation of permission. In addition to the issue of compensation there is also a sanction in the form of a criminal namely: "Any person who intentionally gives false or misleading statements or statements on the label as referred to in Article 100 paragraph (2) shall be liable to a maximum imprisonment of 3 (three) years or a fine a maximum of Rp.6,000,000,000.00 (six billion rupiah)".

While in Law No. 33 of 2014 concerning the guarantee of Halal Products of Business Actors that include Halal Labels are not in accordance with the provisions referred to in Article 38 and Article 39, subject to administrative sanctions in the form of: verbal reprimands; written warning; or revocation of Halal Certificate. Criminal provisions contained in Article 56 which reads: "Business Actors who do not maintain the halalness of Products that have obtained Halal Certificates as referred to in Article 25 letter b, shall be subject to a maximum imprisonment of 5 (five) years or a maximum fine of $\mathrm{Rp}$ 2,000,000,000 , 00 (two billion rupiah)".

In the Republic of Indonesia Government Regulation Number 69 of 1999 concerning Food Labels and Advertisement Article 28 regulates the prohibited trading of food that has exceeded the expiration date, month and year as stated on the Label. While regarding the imposition of sanctions against business actors in the Government regulation, the administrative measures referred to in paragraph (1) include: written warnings; prohibition to temporarily distribute and or order to withdraw food products from circulation; food destruction if it is proven to endanger human health and life; suspension of production for a while; imposition of a maximum fine of $\mathrm{Rp} 50,000,000.00$ (fifty million rupiah), and or; revocation of production permit or business permit.

\section{CONCLUSIONS}

Based on the results of the research and discussion described above, the researcher can conclude as follows: 1) The forms of legal protection for Muslim consumers in Indonesia include among others the Law on Consumer protection, namely Law No. 8 of 1999 which is often referred to as the Consumer Protection Act (UUPK). In the Act Consumer Protection Article 8, specifically for Muslim Consumers associated with other legislation is contained in Law no. 18 of 2012 concerning Food, which is contained in Article 95 concerning Guarantees of Halal Products, hereinafter regulation through guarantees to Muslim consumers in obtaining food products labeled as halal is regulated in Law No.33 of 2014 concerning halal product guarantees contained in 
Article 4 and the last through Government Regulation No. 69 of 1999 concerning Food Labels and Ads that explain halal certification as contained in Article 3, Article 10 and Article 11;2) Legal efforts that can be carried out by the public who feel aggrieved due to products that are not in accordance with the provisions of halal law, one of which can take place through the rules set out in the Consumer Protection Act, among others: First, take Dispute Resolution in Out of court by adopting a Solution through Negotiation, Consultation, Reconciliation, Mediation and Expert Assessment. Second, dispute resolution can be taken through the General Court Path by filing a lawsuit related to Unlawful Acts and the legal sanctions are usually related to Civil Compensation, but in principle both dispute resolution outside or within the Court does not remove the Alleged Criminal Acts committed by Actors Business regarding certain cases. Another effort when referring to the Consumer Protection Act (UUPK), namely Settlement through the Consumer Dispute Settlement Agency (BPSK).

\section{REFERENCES}

\section{Books}

Bambang Sunggono, (2013), Metodologi Penelitian Hukum, RajaGrafindo Persada, Jakarta..

Bambang Imam Supeno, (2014), Pandangan Imam Al-Ghazali Tentang Halal Dan Haram. Insan Amanah, Surabaya.

Johnny Ibrahim, (2012), Teori \& Metodologi Penelitian Hukum Normatif, Bayumedia Publishing, Malang.

Lili Rasjidi dan Ira Thania Rasjidi, (2013), Monograf Filsafat Ilmu, Metode Penelitian Hukum Dan Menggunakan Teori/Konsep Di Bidang Ilmu Hukum, Bandung

Lembaga Pengkajian Pangan, Obat-Obatan dan Kosmetika, PedomanUntuk Memperoleh Sertifikat Halal', MUI Provinsi Jawa Tengah.

Salim HS., dan Erlies Septiana Nurbani, (2013), Penerapan Teori Hukum Pada Penelitian Tesis Dan Disertasi, Raja Grafindo Persada, Jakarta.

\section{Journals}

Afroniyati, Lies. (2014), "Analisis Ekonomi Politik Sertifikasi Halal Oleh Majelis Ulama Indonesia”. Jurnal Kebijakan \& Administrasi Publik. Vol. 18 Number 1. May p. 37-52.

Endah, Nur Hadiati. (2014), "Perilaku Pemberian Kosmetik Berlabel Halal Oleh Konsumen Indonesia”. Jurnal Ekonomi dan Pembangunan, Vol. 22 Number 1, p. 11-25. DOI: 10.14203/JEP.22.1.2014.25-39.

Hasan, K.N. Sofyan Hasan, (2014), "Kepastian Hukum Sertifikasi dan Labelisasi Halal Produk Pangan". Jurnal Dinamika Hukum, Vol. 14 Number 2, , p. 227-238. DOI: 10.20884/1.jdh.2014.14.2.292.

Hidayat, Asep Syarifuddin and Mustolih Siradj. (2015), "Sertifikasi Halal dan Sertifikasi Non Halal”. Jurnal Ahkam, Vol. XV No. 2, , p. 99-210. DOI: 10.15408/ajis. v15 i2.2864.Irena Revin, Suradi, Islamiyati, (2017), Perlindungan hukum bagi konsumen terhadap adanya pemalsuan labelisasi halal pada produk pangan impor, Jurnal Volume 6, Fakultas Hukum Universitas Diponegoro, Semarang,. 
Krishnan, Selvarajah. Mohamad Haniff Hanafi Mohd Aderis. Muhammad Nabil Azman. Mohammad Nazrin Azham Kamaluddin. (2017), "Halal Food: Study on NonMuslim Acceptance". American Journal of Economics, Vol. 7 Number 1,. Pp. 41-45. DOI: 10.5923/j.economics.20170701.05. p. 41-45.

Kurniawan. Budi Sutrisno and Dwi Martini, "Tanggung Jawab Pelaku Usaha Terhadap Pemberian Label Halal Pada Pada Makanan dan Minuman Perspektif Hukum Perlindungan Konsumen”. Jurnal Penelitian Unram, Vol. 18 Number 1. p. 80-96.

Lada, S., Tanakinjal, G.H., and Amin, H. (2009) "Predicting intention to choose halal products using theory of reasoned action". International Journal of Islamic and Middle Eastern Finance and Management. 2(1) p. 66-76. www.emeraldinsight. com/1753-8394.htm.

Nasution, Bahder Johan. (2014), "Upaya Penerapan Sanksi Administratif dan Perizinan sebagai Pembatasan terhadap Kebebasan Bertindak". Asy-Syir'ah Jurnal Ilmu Syari'ah dan Hukum. Vol. 48 Number 1. p. 211-230. DOI: 10.14421/ asysyir'ah.2014. \% 25x.

Nurhayati, Irna. (2009), "Efektivitas Pengawasan Badan Pengawas Obat dan Makanan terhadap Peredaran Produk Pangan Olahan Impor dalam Mewujudkan Perlindungan Konsumen”. Mimbar Hukum. Vol. 21 Number 2. p. 203-222. DOI: 10.22146/ jmh.16265

Suparto, Susilowati. (2016), "Harmonisasi Dan Sinkronisasi Pengaturan Kelembagaan Sertifikasi Halal Terkait Perlindungan Konsumen Muslim Indonesia”. Jurnal Mimbar Hukum. Vol. 28 Number 3. p. 427-438. DOI: 10.22146/jmh.16674.

\section{Website, Internet.}

Wikipedia, Penelitian Kualitatif, https://id.wikipedia.org/wiki/Penelitian kualitatif

Wikipedia, Penelitian Deskriptif, https://id.wikipedia.org/wiki/Penelitian deskriptif

Edukasi PPKn, Macam-Macam Metode Penafsiran Hukum, http://www.edukasippkn. com/2016/06/macam-macam-metode-penafsiran-hukum.html 